\title{
Case Study on Infanticide in South Africa
}

\author{
Bergh LB* \\ Private Practice, Medipark Medical Centre, Gauteng, South Africa
}

Received: 13 Apr, 2019 | Accepted: 01 Jun, 2019 | Published: 07 Jun, 2019

*Corresponding author: Bergh LB, Private Practice, Medipark Medical Centre, Gauteng, South Africa, E-mail: Lorinda.bergh@telkomsa.net

Citation: Bergh LB (2019) Case Study on Infanticide in South Africa. J Psychiatry Ment Health 4(1): dx.doi.org/10.16966/2474-7769.130

Copyright: (C) 2019 Bergh LB. This is an open-access article distributed under the terms of the Creative Commons Attribution License, which permits unrestricted use, distribution, and reproduction in any medium, provided the original author and source are credited.

\author{
Abstract \\ This case study summarizes my therapeutic experience over a period of more than 10 years working with a client convicted of murder of her \\ 3-month-old infant (Infanticide).
}

Keywords: Infanticide; Infant; Psychologist; Inmate; Psychological treatment

\section{Case Study}

My client, referred to as $\mathrm{N}$, a young woman aged 19 when found guilty of the murder of her 3-month-old infant. After a plea-bargain, $\mathrm{N}$ received a 15 -year sentence of imprisonment of which 5 years was suspended for 5 years on condition she not be convicted of murder or any other offence of which violence is an element and for which she is sentenced to direct imprisonment committed in the period of suspension. $\mathrm{N}$ was released on parole after serving 5 years of her sentence.

$\mathrm{N}$ grew up in an affluent black South African family with Christian religious beliefs. Her parents instilled excellent norms and values in their 3 children; $\mathrm{N}$ was the youngest of the siblings. There was no history of any form of abuse, childhood maltreatment or conduct disorder.

Her parents separated when $\mathrm{N}$ was 7 years old and divorced when she was 11 years old. $\mathrm{N}$ experienced the divorce as very traumatic. Her father moved to Cape Town and she grew up with her mother in Johannesburg. Her father, who occupies a senior position in Government, spoilt and overindulged her with everything she wanted, while her mother (a successful entrepreneur) had to discipline and deal with N's mood swings. This led to a strained mother-daughter relationship.

$\mathrm{N}$ started a relationship with $\mathrm{K}$, her co-accused and father of the deceased infant, while she was still at school. She was impregnated by $\mathrm{K}$ on a previous occasion and had an abortion at his insistence. The deceased infant was from her second pregnancy by K. During this pregnancy $\mathrm{K}$ again pressurized her to have an abortion and escorted her to abortion clinics on more than one occasion. $\mathrm{N}$ refused and decided to continue with the pregnancy. During this time K became increasingly physically and emotionally abusive towards her. Despite his behavior she remained obsessed with him and feared being rejected by him. She completed her twelfth grade of secondary school and pursued her tertiary education while being pregnant.
After the birth of the infant, $\mathrm{N}$ felt trapped and unable to bond with the infant, due to K's continued physical and emotional abuse. According to N, K repeatedly told her that he "did not want to see that thing" and that he would never recognize the infant as his first-born. She, however, remained infatuated with $\mathrm{K}$.

$\mathrm{N}$ had no desire to take care of the infant and wanted to continue with her social life as she had done prior to the birth. She had no history of alcohol or any drug abuse. N became increasingly depressed and anxious and often contemplated suicide as well as having thoughts of killing the infant during this time. $\mathrm{N}$ was also angry with her mother who expected her to take care of the infant and discontinue her tertiary studies, which resulted in anger outbursts towards her mother.

A full-time nanny was employed by N's mother to help $\mathrm{N}$ care for the infant while she was away on a business trip. N's mother requested the nanny to ensure that the infant was cared for, bathed, clothed and fed. Despite all these efforts to support $\mathrm{N}$, she continued her egocentric and selfish behavior which directly resulted in the eventual poisoning and murder of the infant.

After the murder, $\mathrm{N}$ was kept at the Police station for 2 days, then moved to holding cells at a prison and later transferred to Weskoppies psychiatric hospital where she remained for 2 months under observation. When $\mathrm{N}$ returned home from the Weskoppies psychiatric hospital, while still awaiting trial, she met a new boyfriend $P$ and quickly embarked on a sexual relationship which led to her falling pregnant again; another unplanned pregnancy.

The psycho-legal report conducted by a clinical psychologist for the defense a few months later, determined that N's intellectual abilities were above average. However, her intellectual abilities were influenced by fluctuating attention and concentration, emotional and personality problems and a high anxiety level. She had a tendency not to persevere when demands were complex and would give up easily. Her social judgment was excellent but she did not apply this in 
practice. She was easily influenced by emotions and her interpersonal relationships were poor. The report noted that $\mathrm{N}$ showed strong traits of borderline personality disorder, was emotionally immature and directed towards her own needs, infatuated with $\mathrm{K}$ and his needs and unable to face consequences of her actions. She was not equipped to take on a mother role for a new born infant. The report indicated that at the time of the offence, $\mathrm{N}$ was able to appreciate the wrongfulness of her actions and was able to act in accordance with such appreciation of the wrongfulness but with diminished capacity due to her clinical depression, deduced from the fact that she did not try to hide the poison and the incriminating evidence against her.

$\mathrm{N}$ was pregnant during her trial and gave birth to her second baby in a private hospital while incarcerated. $\mathrm{N}$ was not allowed to hold the baby as the baby was immediately moved to ICU due to breathing problems and $\mathrm{N}$ was returned to the correctional facility soon after the birth. N and P both signed guardianships over to N's mother as N's mother did not want $\mathrm{N}$ to raise the baby in a prison facility and to prevent $\mathrm{N}$ from harming this baby.

\section{Psychotherapeutic Intervention before, during and after N's Incarceration}

I started psychotherapy with $\mathrm{N}$ as a private clinical psychologist to establish a relationship before she was incarcerated in order to prepare her for her incarceration due to my knowledge and experience of correctional services. The Correctional Services Act (Act No. 111 of 1998) [1] and the Correctional Services Amendment Act (Act No. 32 of 2001) [2] provides for inmates to see a private psychologist (as well as a medical practitioner, dentist and psychiatrist) at their own cost. All N's psychotherapeutic, psychiatric, medical and dental sessions were paid for by her mother.

I conducted psychotherapy from 2011 with $\mathrm{N}$ at the Pretoria Female Correctional Centre for 90 psychotherapy sessions, of which 47 were individual psychotherapy sessions of 1 hour each and 43 consultation visits of 2 hours each with her mother and her baby. Regular prison consultation visits were conducted to ensure $\mathrm{N}$ bonded with the baby, that the baby was thriving emotionally and physically and to intervene when necessary.

$\mathrm{N}$ was initially extremely uncertain of herself and felt isolated and detached from her new-born baby. She found it difficult to hold the baby and expressed "feeling empty". When the baby was 3 weeks old, her mother brought the baby to the correctional facility for the first consultation visit, N's behavior during the visit was emotionally guarded. She was able to hold the baby but often looked at her mother for guidance and support. Initially $\mathrm{N}$ found it difficult to bond with the baby as she only saw her baby for approximately 1 hour per week and continued to feel alienated from her baby despite regular consultation visits.

N's bonding with her baby improved after 3 months, possibly because of the passing of the critical 3-month period directly related to the death/murder of her infant. $\mathrm{N}$ portrayed a positive mind-set throughout her incarceration and found it increasingly easier to bond with her baby as time went by.

$\mathrm{N}$ had no psychotic symptoms before or after her incarceration, she also did not show any remorse.

\section{Theoretical Perspectives on Infanticide}

For most pregnant woman the psychological transition to motherhood begins at pregnancy. However, some women do not experience the joy of being pregnant due to various stressors that makes the psychological transition to motherhood extremely difficult. Gunn and Taylor [3] indicate that approximately 50\% of women convicted of Infanticide kill their children in the context of unwanted or concealed pregnancies.

In N's case the following stressors made it difficult for her to bond with the fetus and the infant:

- N's pregnancy with K was an unwanted $2^{\text {nd }}$ pregnancy.

- K did not want to have the infant, insisted on abortion, and was emotionally and physically abusive. $\mathrm{K}$ called the infant "that thing".

- K impregnated another woman while in a relationship with $\mathrm{N}$.

- $\mathrm{N}$ was expected to stay at home after the birth, stop her studies and take care of the infant.

- $\mathrm{N}$ experienced her family as being unsupportive.

The literature on postpartum depression clearly indicates that women who kill their new-born and/or infants suffer from distinct and recognized mental disorders at the time of the killing [4]. According to Spinelli MG [4] postpartum psychiatric illness constitutes a serious complication at birth, with the most tragic outcomes being infanticide and suicide. She also mentions that Infanticide is frequently committed by women with a major depressive disorder, bipolar mood disorder, or major depressive disorder with psychotic features [4]. Sometimes these women have also been characterized as having a personality disorder, because there is no other specific explanation to account for the illness-this is relevant in the case of $\mathrm{N}$ as she was diagnosed with strong traits of borderline personality disorder with some traits of antisocial personality disorder, an unstable mood and clinical depression during her psychological evaluation for the Court.

Spinelli MG [4] found that most women do not experience postpartum symptoms at the trial as postpartum syndromes are often transitory conditions-this is relevant in the case of $\mathrm{N}$ as postpartum depression was never diagnosed at the time of her psychological evaluation before or during her court case.

Spinelli MG [4] found that many of these women are often victims of unplanned/unprotected pregnancies-relevant in the case of $\mathrm{N}$.

The definition of Infanticide according to Spinelli MG [4] indicates that "it applies to the killing of an infant under 1 year of age by its mother". The definition rests on the below 2 assumptions, all applicable in the case of $\mathrm{N}$ :

- Child bearing disturbs the balance of the woman's mind;

- It is likely to be a consequence of the mental instability associated with childbearing.

For Spinelli MG, Infanticide is the ultimate failure of bonding [4] as pre-existing conflicts re-emerge (such as the relationship with the own mother) and therefore these mothers are not emotionally ready and do not really accept the responsibility of motherhood.

All of the aforementioned are relevant factors in the case of $\mathrm{N}$, herself still in the late stages of adolescence. We know that young people today continue their education for longer, there is a delay in terms of marriage and parenthood, etc. and these are all factors that challenge old perceptions of when adulthood really begins, as some scientists now say that Adolescence lasts from the ages of 10-24 years.

Spinelli MG [4] indicates that Infanticide is not caused by a single factor and that there are different types of Infanticide, namely: 
- Assisted/coerced infanticide (in conjunction with their partners where the intimate partners are violent or abusive) -relevant for N.

- Neglect, related infanticide- not relevant for $\mathrm{N}$.

- Abuse, related infanticide-relevant for $\mathrm{N}$.

- Mental-illness infanticide (severe mental illness, acute or chronic) in persons who clearly are not prepared for the task of mothering-relevant for $\mathrm{N}$.

The risk factors for Infanticide according to Spinelli MG [4] are the following:

- Mothers younger than 17 years.

- Mothers aged between 17-19 years-relevant for N

Spinelli MG [4] indicates that many of these women also experience pregnancy denial. As with other forms of denial, denial of pregnancy occurs along a spectrum of severity. Sometimes the existence of pregnancy is cognitively acknowledged but its emotional significance is denied. Sometimes the knowledge of pregnancy is briefly recognized (cognitively) but suppressed to the point of unawareness [4]. Spinelli MG identifies 3 different types of pregnancy denial namely:

- Affective denial (feelings of detachment from the infant)-this detachment contradicts the usual heightened emotional state of the pregnant woman that is associated with the process of early bonding. Woman with this form of denial continue to think, feel and behave as though they were not pregnant-relevant for $\mathrm{N}$.

- Pervasive denial-not relevant for $\mathrm{N}$.

- Psychotic denial-not relevant for N.

There are also different reasons for denial according to Spinelli [4].

- Cognitive models of denial that can include the threat of painful affects as well as physical or external threats that promotes cognitive dissonance-relevant for $\mathrm{N}$.

- Emotional stressors related to pregnancy denial and a fear of being abandoned by a partner-relevant for $\mathrm{N}$.

Because of the difficulty in identifying the symptoms of postpartum depression it can often be misinterpreted by family/health care professionals [4] and therefore the illness may go unrecognized and untreated. Spinelli indicates that out of fear or guilt the mother may not share her thoughts and fears with others- $\mathrm{N}$ was only diagnosed and treated for postpartum depression by a psychiatrist after the birth of the infant and shortly before her trial when she visited her father in Cape Town. Her mother, unfamiliar with postpartum depression and the possible outcomes thereof, stopped the medication when $\mathrm{N}$ returned to Johannesburg and put $\mathrm{N}$ on herbal remedies. $\mathrm{N}$ never expressed or shared her thoughts and fears with her mother about her raising her infant as she "feared" her mother and did not want to oppose her. She also did not share her thoughts with anyone else which led to an escalation of her depression and anxiety.

After $\mathrm{N}$ was incarcerated, $\mathrm{I}$ referred $\mathrm{N}$ to a psychiatrist who prescribed anti-depressants. I explained at length to both $\mathrm{N}$ and her mother the vital importance of $\mathrm{N}$ receiving anti-depressants and/or a mood stabilizer regularly as well as the possibility of future postpartum depression if she were to fall pregnant again.

$\mathrm{N}$ and her mother initially came for individual and joint therapy sessions after $\mathrm{N}$ was placed on parole during the $1^{\text {st }}$ and $2^{\text {nd }}$ year, but rarely came for therapy sessions from the $3^{\text {rd }}$ year onwards.
At first it seemed as if $\mathrm{N}$ adapted and bonded well with her baby. This did not last and N's mother indicated during her last consultation with me in 2018 that N's behavior had returned to being increasingly self-centered, demanding and prone to lying. $\mathrm{N}$ was secretly contacting and meeting up with $\mathrm{P}$, despite the fact that she knew $\mathrm{P}$ was going to get married to another woman. The information provided by the mother and confirmed with $\mathrm{N}$ during a separate consultation reconfirmed N's traits of possible borderline or antisocial personality disorder.

The continuous negative and manipulative behavior of $\mathrm{N}$ behind her mother's back to obtain custody of the child (by then 8 years old) caused N's mother to approach the High Court of South Africa for a sole custody order, as she became increasingly concerned about the future health, safety and general wellbeing of her grandchild should the child ever be placed in the care of N. A High Court Order was granted and N's mother was awarded sole custody due to the fact that $\mathrm{N}$ is not able to provide the child with a similar balanced, constructive, healthy and positive upbringing as what her mother had already provided for a period of over 8 years.

\section{Summary}

South Africa has one of the world's highest reported homicide rates involving babies, and is considered a "serious social and public health problem" [5,6]. Researchers, led by Naeemah Abrahams of the gender and health research unit at the South African medical research council in Cape Town, estimate that the South African rates for neonaticide (killing a child within the first 28 days of life) is 19.6 per 100,000 live births, and for infanticide (killing a child under one year) is 27.7 per 100,000 live births, but this estimate may well be underestimated. A review of 40 years of research on both infanticide and neonaticide showed the incidence in developed countries-such as the United States, United Kingdom and New Zealand-to range from 2.1 to 6.9 per 100,000 live births.

This case study of $\mathrm{N}$ was my first experience with infanticide and I share here my personal experience with others as research about infanticide is not easily available, and research figures are often underestimated due to poor identification, reporting and recording of these deaths, especially in poorer and more rural settings. This topic also receives little research attention in South Africa.

\section{Note}

- In South Africa you are convicted of murder and nor for Infanticide.

- The term infant is used to indicate the murdered child while the term baby is used for the child that lived.

- South Africa does not have a law that decreases the penalty for mothers who kill their children up to one year of age.

The Diagnostic and Statistical Manual of Mental Disorders (DSM $5,2013)$ does not include postpartum depression as a diagnosis.

\section{References}

1. Correctional Services Act (1998) Government Gazette, Cape Town, South Africa.

2. Correctional Services Amendment Act (2001) Government Gazette, Cape Town, South Africa.

3. Gunn T, Taylor D (1995) Clinical, Legal and Ethical issues. Forensic Psychiatry 8: 49-53. 
4. Spinelli MG (2003) Infanticide: Psychosocial and Legal Perspectives on Mothers Who Kill. American Psychiatric Publishing, Washington DC.

5. Naeemah Abrahams (2016) Baby killing in South Africa-uncovering the unthinkable. Medical Brief.

6. Marks MN (2009) Characteristics and causes of infanticide in Britain. Int Rev Psychiatry 8: 99-106. 